$\mathrm{Y}_{\mathrm{s}}$

влажнение кожи как фактор профилактики преждевременного старения

\author{
А.Г. Пашинян ${ }^{1}$, С.А. Хейдар ${ }^{1}$, Г.Б. Арутюнян ${ }^{1}$, Е.В. Донцова²
}

1 ГБОУ ВПО «Российский национальный исследовательский медицинский университет им. Н.И. Пирогова» Минздрава России

117997, Москва, ул. Островитянова, д. 1

2 ГБОУ ВПО «Воронежская государственная медицинская академия им. Н.Н. Бурденко» Минздрава России 394036, Воронеж, ул. Студенческая, 10

\footnotetext{
Освещены вопросы возрастных изменений кожи. Представлены данные, подтверждающие клиническую эфрфективность увлажняющих средств лечебной косметики гаммы Норева Акварева Дерматологической лаборатории Урьяж по восстановлению естественной водосберегающей структуры эпидермиса у пациентов с сухой кожей за короткий период.
}

Ключевые слова: сухая кожа, натуральный увлажняющий фактор кожи, увлажняющие косметические средства для кожи лица.

Контактная информация: stso@rambler.ru. Вестник дерматологии и венерологии 2013; (4): 104_107.

\title{
Skin moisturizing as a factor preventing premature skin ageing
}

\author{
A.G. Pashinyan ${ }^{1}$, S.A. Heidar ${ }^{1}$, G.B. Arutyunyan', Ye.V. Dontsova²
}

${ }^{1}$ The Russian National Research Medical University named after N.I. Pirogov (RNRMU) Ostrovityanova str 1, 117997, Moscow, Russia

2 Voronezh State Medical Medical Academy (VSMA)

Studencheskaya str 10, 394036, Voronezh, Russia

\begin{abstract}
The authors describe issues related to age-related changes in the skin. They present data confirming the clinical efficacy of hydration cosmetic drugs belonging to the Noreva Aquareva line by Laboratoires Dermatologiques d'Uriage aimed at renewing the natural moisture-preserving epidermis structure in patients with dry skin within a short period of time.
\end{abstract}

Key words: dry skin, natural skin moisturizing factor, hydration facial skin cosmetic products.

Corresponding author: stso@rambler.ru. Vestnik Dermatologii i Venerologii 2013; 4: 104_107. 
Одной из причин обращения пациентов к дерматологу является сухость кожи, которая может возникнуть в любом возрасте в силу эндогенных (гормональный дисбаланс, хроническая почечная, печеночная недостаточность, различные виды атопии, заболевания урогенитального тракта) или экзогенных причин, в том числе климатических условий [1-3].

Кожа обладает универсальной системой регуляции и саморегуляции, обеспечивающей поддержание гомеостаза. Ее основные функции определяются необходимостью быстрого реагирования на постоянно изменяющиеся условия внешней среды [3].

По данным исследователей, на интенсивность обменных процессов в коже влияет степень увлажненности эпидермиса и состояние дермальных структур. Дерма состоит на 99\% из воды, мальпигиевый слой - на $90 \%$, роговой слой содержит от 15 до $35 \%$ воды [4].

Роговой слой эпидермиса является важной барьерной структурой эпидермиса, обеспечивающей относительно постоянный показатель $\mathrm{pH}$ кожи, регулирующей трансэпидермальную потерю воды и защищающей от проникновения химических веществ и микроорганизмов [5, 6].

В работах ряда исследователей установлено, что уменьшение продукции поверхностных липидов кожи приводит к увеличению трансэпидермальной потери воды. Пониженный уровень церамидов вызывает появление дефектов в межклеточных липидных пластах и, соответственно, нарушает их барьерную функцию. Это обусловливает повышенную проницаемость рогового слоя для воды и ее потерю путем испарения, что приводит к дегидратации эпидермиса и формированию клинических проявлений ксероза $[7,8]$.

При повреждении рогового слоя повышается трансэпидермальная потеря воды. Также большое значение имеет уменьшение концентрации натурального увлажняющего фрактора кожи, который вырабатывается из фрилагрина корнеоцитов [9]. Компоненты натурального увлажняющего фрактора (НУФ) - низкомолекулярные гигроскопичные вещества (свободные аминокислоты, мочевина, молочная кислота, пироглутамат натрия), которые связывают и удерживают молекулы воды и тем самым создают дополнительную водную оболочку вокруг роговых чешуек, повышая их пластичность [1].

Нарушение связывания жидкости в роговом слое, обусловленное действием экзогенных токсинов или эндогенных факторов, приводит к нарушению гидролипидной мантии рогового слоя, которая обладает водоотталкивающими свойствами и регулирует трансдермальную потерю воды, а также к уменьшению продукции липидов поверхности кожи. Нарушение гидролипидного баланса кожи при снижении активности сальных и потовых желез, а также в результате уменьшения образования липидов, продуцируемых кератиноцитами и повышением уровня трансэпидермальной потери воды, приводит к развитию стойкого патологического состояния - ксероза кожи [8].

В ряде исследований было установлено, что зимой у пациентов с выраженным ксерозом уровень гидратации рогового слоя ниже на $25 \%$, чем у пациентов без признаков ксероза $[10,11]$.

Сухость кожи носит циклический характер с возрастной тенденцией к ухудшению состояния, поэтому очень важен рациональный косметический уход, адаптированный к фризиологии и строению кожи [12].

Возрастные изменения кожи сопровождаются характерными объективными и субъективными косметическими, психофизиологическими и психологическими функциональными нарушениями организма человека, требующими проведения восстановительных мероприятий по первичной или вторичной профилактике указанных изменений в рамках программы «антистарения» [13-15].

Первые морфологические признаки биологического старения отмечаются уже в возрасте 25 лет и заключаются в уменьшении количества эластических и нарушении структуры коллагеновых волокон. Количество эластических волокон прогрессивно уменьшается и составляет у 18-летних 7,1\%, в 25-34 года - 6\%, в 35-44 года - 4,1\% и у пациентов старше 45 лет 2,6\% [15-17].

Для разработки эфффективных, научно обоснованных методов коррекции возрастных изменений кожи перспективным представляется изучение ее морфофункциональных характеристик, механизмов старения. Современные неинвазивные методы исследования (се-

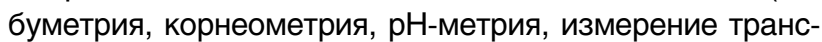
эпидермальной потери воды, кутометрия, лазерная допплеровская фрлоуметрия, визиосканирование, ультразвуковое дермасканирование) объективно оценивают функциональные и структурные изменения кожи, уровень ее дегидратации и другие показатели [5, 18-20].

Теоретической основой для создания косметических средств нового поколения, предназначенных для нормализации структуры и функций барьерных систем кожи, стала концепция корнеотерапии - лечения и профилактики заболеваний и патологических изменений кожи в контексте корнеологии, учения о роговом слое, разработанном американским дерматологом Альбертом Клигманом [20-22].

А. Клигман рассматривал возможности коррекции дерматозов (атопического дерматита, экземы, псориаза и др.) посредством восстановления эпидермального барьера кожи, определяющими компонентами защитных функций которого являются липиды рогового слоя [21]. Структурная организация липидов и ее связь с нормальным и патологическим состоянием кожи послужили поводом к пересмотру отношения к роговому слою как к просто механическому барьеру. Создание препаратов, наносимых на кожу, как косметических, так и фрармацевтических, с этого момента происходит с учетом 
состояния естественного состава липидного барьера эпидермиса. Поэтому роль традиционных эмолентов вазелина, ланолина пересматривается и проводится поиск новых систем доставки липидов в кожу [7, 8, 22].

Устранить сухость кожи можно различными способами: путем создания на поверхности кожи окклюзии, препятствующей трансэпидермальной потере влаги; применения заместительной терапии; использования эмолентов; создания осмотического увлажнения; восстановления эпидермального барьера; активации синтеза аквапоринов [23-25].

Уровень гидратации рогового слоя - важный индикатор его барьерных свойств. Задачей лечебно-косметических средств является восстановление барьерной структуры эпидермиса и нормализация уровня трансэпидермальной потери воды. С этой целью в средства ухода включают определенные липиды (церамиды, холестерин, свободные жирные кислоты, силиконовые масла, воски, полисахариды, белковые гидролизаты, полигликоли, компоненты натурального увлажняющего фрактора), мочевину, молочную кислоту, свободные аминокислоты [5, 7, 8, 26].

Французскими исследователями [27] были опубликованы результаты изучения влияния увлажняющих лечебно-косметических средств линии Норева Акварева Дерматологической лаборатории Урьяж на основе термальной воды «Урьяж» (кремов легкой и насыщенной текстуры, экспресс-маски, молочка для тела, интенсивного ночного увлажняющего ухода) на уровень гидратации сухой чувствительной кожи [28, 29].

Известно, что эфффективность косметического средства определяется его составом. В состав крема легкой текстуры входит Гидрастим 4С, фррагментированая гиалуроновая кислота, 11\% увлажняющих компонентов: глицерина, эфира жожоба, сквалена, масла зерен кунжута.

Гидрастим 4С увеличивает количество кератиноцитов и ускоряет их созревание для восстановления защитного барьера кожи, ограничения трансэпидермальной потери воды. Активизирует натуральный фактор увлажнения путем стимуляции образования профриларгина и филаргина. Фрагментированная гиалуроновая кислота создает запасы воды в глубоких слоях эпидермиса, стимулирует обменные процессы в коже, увеличивает объем межклеточного вещества дермы, количество его структурных элементов (гликозаминогликанов и каркасных белков) за счет активизации синтетической активности фибробластов. Она способна связывать в 1000 раз больше воды, чем весит сама молекула гиалуроновой кислоты [30].

Для сухой обезвоженной кожи используют крем насыщенной текстуры, в состав которого, кроме перечисленных ингредиентов, входят также Омега 3 и 6 незаменимые ненасыщенные жирные кислоты, 13,5\% увлажняющих компонентов: глицерина, алкана и стеарата.
Были представлены данные, полученные при использовании регрессивного теста Клигмана (для тестирования эфффективности увлажняющих средств и влияния дерматотропных прапаратов на увлажнение кожи), корнеометрии и теваметрии. Согласно полученным данным, в результате применения увлажняющих кремов Норева Акварева легкой и насыщенной текстуры была отмечена положительная динамика повышения увлажненности и эластичности в зонах воздействия кремов. Уровень увлажнения через 24 ч. после использования крема Акварева легкой текстуры увеличился на 18\%, после нанесения крема Акварева насыщенной текстуры - на 20\%.

В состав интенсивно увлажняющей экспресс-маски входят Гидрапорин (экстракт солероса - протеин, извлекаемый из морских растений), фрагментированая гиалуроновая кислота, увлажняющий комплекс, основанный на жемчужинах ледниковой воды. Гидрапорин стимулирует выработку мочевины в НУФ, увеличивает выработку связывающих протеинов, стимулирует выработку фриларгина, играет ключевую роль в выработке липидов рогового слоя.

Маску наносят 1-2 раза в неделю тонким слоем на 5-10 мин., затем удаляют остатки салфеткой.

По данным М. Mathey и соавт. [27], после применения увлажняющей экспресс-маски через 8 ч. отмечается увеличение степени увлажненности кожи на $40 \%$.

Одним из средств профилактики сухости кожи является увлажняющее молочко для кожи Норева Акварева. Проведенное французскими дерматологами исследование показало заметное мгновенное и длительное улучшение состояния обезвоженной кожи [31].

В состав интенсивного ночного увлажняющего крема Норева Акварева входят 6\% Гидрастим 4С, липиды. Доказано, что местное применение липидов (церамидов, фросфолипидов, триглицеридов) ускоряет восстановление липидного барьера кожи, при этом оптимальное соотношение церамидов, жирных кислот и холестерина составляет 1:1:1-3:1:1.

Патогенез действия увлажняющих средств включает три этапа: очень быстрое - менее 1 ч. уменьшение трансэпидермальной потери воды благодаря окклюзивным свойствам; проникновение в роговой слой эпидермиса и замещение недостатка липидов, фрормирующих кожный барьер, - менее 6 ч.; проникновение в эпидермис глубже рогового слоя и интеграция липидов, идентичных тем, которые содержатся в коже, в ламеллярные тельца. Данный эффект длится от 6 до 24 ч. в зависимости от тяжести повреждения кожного барьера.

Таким образом, в результате открытого исследования, проведенного французскими дерматологами, было установлено, что лечебно-косметические средства линии Норева Акварева Дерматологической лаборатории Урьяж активно восстанавливают естественную водосберегающую структуру эпидермиса за короткий период и могут быть применены в качестве профрилактики преждевременного старения кожи. I 


\section{Литература}

1. Mariko E., Motoki O., Tomohiro K., Motoji T. Effect of exposure of human skin to a dry environment. Skin Res Technol 2002; 8(2): 212-218.

2. Tokumura F., Umekage K., Sado et al. Skin irritation due to repetitive application of adhesive tape: the influence of adhesive strength and seasonal variability. Skin Res Technol 2005; 11(2): 102-106.

3. Black D., Del Pozo A., Lagarde J.M., Gall Y. Seasonal variability in the biophysical properties of stratum corneum from different anatomical sites. Skin Res Technol 2000; 6(2): 70—76.

4. Baran R., Maibach H.I. Textbook of cosmetic Dermatology. Martin Dunitz Ltd 1998; 99-167.

5. Schmid-Wendtner M.H., Korting H.C. The pH of the skin surface and its impact on the barrier function. Skin Pharmacol Physiol 2006; 19(6): 296-270.

6. Braff M.H., Bardan A. et al. Cutaneous defense mechanisms by antimicrobial peptides. J Invest Dermatol 2005; 125: 9-13.

7. Jungersted J.M., Hellgren L.I., Jemec G.B. Agner T. Lipids and skin barrier function-a clinical perspective. Contact Dermatitis 2008; 58(5): 255-262.

8. Plasencia I., Norlen L., Bagatolli L.A. Direct visualization of lipid domains in human skin stratum corneum's lipid membranes: effect of pH and temperature. Biophys J 2007; 93(9): 3142—55.

9. Araviyskaya E.R. Skin barrier properties and basic care: innovations in theory and practice. Vestn dermatol venerol 2010; 6: 135-139. [Аравийская Е.Р., Соколовский Е.В. Барьерные свойства кожи и базовый уход: инновации в теории и практике. Вестн дерматол и венерол 2010; 6: 135-139.]
10. Poust J., Newburger A., Sander S. Soothe dry winter skin. Prevention 2001; 53(11): 96-97.

11. Tokumura F., Umekage K., Sado et al. Skin irritation due to repetitive application of adhesive tape: the influence of adhesive strength and seasonal variability. Skin Res Technol 2005; 11(2): 102-106.

12. Lautenschläger Hans. Corneotherapy and antiaging. Profi Kosmetik 2005; 8: 36-37.

13. Fisher G.J. The pathophysiology of photoaging of the skin. Cutis 2005; 75: (2): 5-9.

14. Hashizume H. Skin aging and dry skin. J. Dermatol 2004; 31: 603-609.

15. Roberts W.E. Dermatologic problems of older women. Dermatol Clin 2006; 24: 271-280.

16. Martha Y. Petersen. Aging of skin. The biology of skin N.Y. 2003; 13: 209-211.

17. Seyfarth F., Schliemann S. et al. Dry skin, barrier function and irritant contact dermatitis in the elderly. Clin Dermatol 2011; 29(1): 31—36.

18. Elias P.M., Ghadially R. The aged epidermal permeability barrier: basis for functional abnormalities. Clin Geriatr Med 2002; 18: 103_-120.

19. Sadby-Moler J., Wult H.Ch. Ultrasonographic subepidermal low-ecnogenic band, dependence of age and body site. Scin restechnal 2004; 10(I): 57

20. Lautenschläger Hans. History and current aspects of corneotherapy. Kosmetische Medizin 2005; 26 (2): $58-60$.

21. Kligman A. Corneotherapy, a new approach to the treatment of chronic dermatoses Japanese $\mathrm{J}$ of Dermatol 2000; 110(4): 768

22. Kapes B. Treatment from the outside-in corneotherapy unveiled as a possible new directive for stratum corneum. Dermatology Times 2004; 1.
23. Tkachenko S., Ernandes E. Akvaporiny v regulyatsii vodnogo balansa kozhi. Kosmetika i meditsina 2011; 2: 26-33. [Ткаченко С., Эрнандес Е. Аквапорины в регуляции водного баланса кожи. Косметика и медицина 2011; 2: 26-33.]

24. Moncrieff G., Cork M., Lawton S. et al. Use of emollients in dry skin conditions: consensus statement. Clin Exp Dermatol 2013; 38: 231—238.

25. Pashinyan A.G., Gordiyenko Ye.S., Dzhavayeva D.G. Shahnovich A.A. Advanced moisturizing products for the sensitive skin therapy. Vestn dermatol i venerol 2011: 3: 38-40. [Пашинян А.Г. Гордиенко Е.С., Джаваева Д.Г., Шахнович А.А. Современные увлажняющие средства ухода за чувствительной кожей. Вестн дерматол и венерол 2011; 3: 38-40.]

26. Choi M.J., Maibach H.I. Role of ceramides in barrier function of healthy and diseased skin. Am J Clin Dermatol 2005; 6(4): 215-223.

27. Mathey M.F.; Allart, J.C; Lefèvre J.M; Peyrot J Assessment of moisturizing potential of a cosmetic range by 24-hour moisturizing kinetics.: Scientific review - noreva-LED- 2011; 36-47.

28. Mousli M. et al. Evaluation of inhibiting effects of Uriage spring water on release of mastocytes provoked by peptides. Nouv. Dermatol.1996; 15: 307-314.

29. Beauvais $F$. et al. In vitro effects of Uriage spring water on the apoptosis of human eosinophils. Fund Clin Pharmacol 1998; 12: 446—450.

30. Stern R., Asari A., Sugahara K.N. Hyaluronan fragments: an information-rich system. Eur J Cell Biol 2006; 85(8): 699-715.

31. Margolina A.A., Ernandes E.I., Zaykina O.E. Novaya kosmetologiya. M, 2002. 208. [Марголина А.А., Эрнандес Е.И., Зайкина О.Э. Новая косметология. М., 2002. 208.]

об авторах:

А.Г. Пашинян — Д.м.н., профессор кафедры дерматовенерологии лечебного факультета ГБОУ ВПО «РНИМУ им. Н.И. Пирогова», Москва

С.А. Хейдар — к.м.Н., доцент касфедры дерматовенерологии лечебного факультета ГБОУ ВПО «РНИМУ им. Н.И. Пирогова», Москва

Г.Б. Арутюнян — К.М.Н., ассистент кафредры дерматовенерологии лечебного фракультета ГБОУ ВПО «РНИМУ

им. Н.И. Пирогова», Москва

Е.В. Донцова - к.м.н., ассистент касеедры дерматовенерологии ГБОУ ВП0 «Воронежская государственная медицинская академия им. Н.Н. Бурденко» 